Mgr Jarosław Sadowski*

\title{
MOŻLIWOŚĆ FINANSOWANIA WSPÓŁPRACY ZAGRANICZNEJ POWIATÓW I GMIN ZE ŚRODKÓW UNII EUROPEJSKIEJ
}

Współpraca zagraniczna podejmowana przez powiaty i gminy jest dzisiaj dość powszechną praktyką. Podstawą prawną prowadzenia współpracy międzynarodowej przez samorządy jest artykuł 172 Konstytucji Rzeczypospolitej Polskiej stwierdzający, że ,jednostka samorządu terytorialnego ma prawo przystępowania do międzynarodowych zrzeszeń społeczności lokalnych i regionalnych oraz współpracy ze społecznościami lokalnymi i regionalnymi innych państw". ${ }^{431}$ Przepis ten odpowiada artykułowi 10 ust. 2 i 3 ratyfikowanej w 1993 roku Europejskiej Karty Samorządu Terytorialnego. ${ }^{432}$ Podkreślić należy jednak, że w tym samym artykule Konstytucji zapisano, iż zasady takiej działalności powinny zostać określone w ustawie. Ustawa z dnia 8 marca 1990 roku o samorządzie gminnym w art. 7 ust. 1 pkt 20 wśród zadań własnych gminy wymienia sprawy z zakresu ,,współpracy ze społecznościami lokalnymi i regionalnymi innych państw" ${ }^{433} \mathrm{Z}$ kolei Ustawa z dnia 5 czerwca $1998 \mathrm{r}$. o samorządzie powiatowym ${ }^{434} \mathrm{w}$ art. 12 pkt 9a zastrzega do wyłącznej kompetencji rady powiatu ,podejmowanie uchwał w sprawach współpracy ze społecznościami lokalnymi innych państw oraz przystępowania do międzynarodowych zrzeszeń społeczności lokalnych”. Art. 75a tejże ustawy stanowi, że ,zasady przystępowania powiatu do międzynarodowych zrzeszeń społeczności lokalnych i regionalnych określają odrębne przepisy". Jako przykład takich przepisów można wskazać chociażby Ustawę z dnia 7 listopada 2008 r. o europejskim ugrupowaniu współpracy terytorialnej. ${ }^{435}$ Można pokusić się o stwierdzenie, że w obecnym stanie prawnym samorządy mają szereg możliwości rozwiązywania swoich problemów, korzystając ze współpracy zagranicznej. Jednocześnie granica państwowa, uważana jeszcze niedawno za największą barierę we wzajemnych stosunkach regionów, nie stanowi obecnie już

Wicedyrektor ds. Rynku Pracy w Wojewódzkim Urzędzie Pracy w Białymstoku.

431 Dz.U. z 1997 r. Nr 78, poz. 483 z późn. zm.

432 Dz.U. z 1994 r. Nr 124, poz. 607.

433 Dz.U. z 2001 r. Nr 142, poz.1591 z późn. zm.

434 Dz.U. z 2001 r. Nr 142, poz. 1592 z późn. zm.

435 Dz.U. z 2008 r. Nr 218, poz. 1390. 
takiej przeszkody w podejmowaniu wspólnych działań. ${ }^{436}$ Akcesja Polski do Unii Europejskiej dała samorządom możliwość finansowania współpracy zagranicznej w oparciu o środki pochodzące z funduszy unijnych. Niniejszy artykuł ma na celu wskazanie - w sposób zwięzły i przejrzysty - istniejących obecnie realnych możliwości finansowania tejże współpracy w oparciu o środki Unii Europejskiej.

Opisując możliwości finansowania współpracy międzynarodowej samorządów ze środków Unii Europejskiej, należy podkreślić duże znaczenie współpracy regionów w unijnej polityce spójności. Wyrazem tego jest fakt, iż polityka regionalna Unii Europejskiej (określana też mianem „,polityki spójności”) jako jeden z najważniejszych celów zakłada tzw. Europejską Współpracę Terytorialną. Rozporządzenie Rady (WE) nr 1083/2006 z dnia 11 lipca 2006 r. ustanawiające przepisy ogólne dotyczące Europejskiego Funduszu Rozwoju Regionalnego, Europejskiego Funduszu Społecznego oraz Funduszu Spójności i uchylające rozporządzenie (WE) nr 1260/99, ${ }^{437}$ zwane dalej Rozporządzeniem nr 1083/2006, definiuje ten cel, wskazując na efekty, które mają być dzięki niemu osiągnięte. W art. 3 ust. 2 lit. c przywołanego rozporządzenia czytamy, iż cel Europejska Współpraca Terytorialna ,jest ukierunkowany na umacnianie współpracy transgranicznej poprzez wspólne inicjatywy lokalne i regionalne, umacnianie współpracy transnarodowej za pomocą działań sprzyjających zintegrowanemu rozwojowi terytorialnemu powiązanemu z priorytetami Wspólnoty oraz umacnianie współpracy międzyregionalnej i wymiany doświadczeń na właściwym szczeblu terytorialnym". Treść cytowanego przepisu wskazuje więc na trzy płaszczyzny współpracy międzynarodowej służące realizacji tego celu:

1) współpracę transgraniczną,

2) współpracę transnarodową,

3) współpracę międzyregionalną.

Istota różnicy między trzema wskazanymi wyżej typami współpracy została wskazana w art. 7 Rozporządzenia nr 1083/2006. Podstawą do przeprowadzenia linii demarkacyjnej pomiędzy tymi rodzajami współpracy, co do zasady, jest obszar terytorialny, w ramach którego można realizować wspólne przedsięwzięcia. W przypadku programów współpracy transgranicznej są to obszary przylegające do granic państwowych. W ramach programów współpracy transnarodowej w grę wchodzą duże zgrupowania europejskich regionów z kilku lub kilkunastu państw. Współpracą międzyregionalną są z kolei objęte wszystkie regiony Unii Europejskiej.

Poszczególne typy programów są zróżnicowane pod względem tematyki i zasięgu geograficznego. Programy transgraniczne służą przede wszystkim budowa-

436 Zob. J. Szymański, Podstawowe instrumenty prawne współpracy transgranicznej w ramach Rady Europy [w:] „Białostockie Studia Prawnicze”, zeszyt 9, 2011, s. 90.

Dz. Urz. UE L 210 z dnia 31.07.2006 r. 
niu więzi łączących społeczności po obu stronach granicy. Ich realizacja służy wzmocnieniu współpracy poprzez wzrost liczby wspólnych inicjatyw dotyczących między innymi ochrony środowiska, rozbudowy infrastruktury, wymiany kulturalnej czy wzajemnych kontaktów młodzieży. $Z$ kolei programy transnarodowe stanowią szansę dla wsparcia bardziej innowacyjnych projektów dotyczących zagadnień istotnych dla obszarów należących do kilku państw. Sprzyjają zintegrowanemu rozwojowi UE poprzez inicjowanie planów i koncepcji prowadzących do realizacji ponadnarodowych przedsięwzięć. Współpraca międzyregionalna, obejmująca obszar całej UE, służy wymianie doświadczeń i dobrych praktyk, a tym samym wzmacnia potencjał instytucji i samorządów w zakresie mechanizmów wspierania rozwoju regionalnego. ${ }^{438}$

Jak w praktyce przedstawiają się możliwości dane polskim samorządom w zakresie tych trzech potencjalnych płaszczyzn współpracy międzynarodowej?

Najprościej odpowiedzieć na to pytanie, wskazując, że Polska uczestniczy w 10 programach Europejskiej Współpracy Terytorialnej. Jest to 7 programów współpracy transgranicznej, 2 programy współpracy transnarodowej oraz 1 program współpracy międzyregionalnej. Programy Europejskiej Współpracy Terytorialnej z udziałem Polski w ramach współpracy transgranicznej to:

1) Polska (województwo lubuskie) - Brandenburgia,

2) Meklemburgia/Pomorze Przednie-Brandenburgia-Polska (województwo zachodniopomorskie),

3) Saksonia-Polska,

4) Czechy-Polska,

5) Polska-Słowacja,

6) Południowy Bałtyk (Polska-Szwecja-Dania-Litwa-Niemcy),

7) Litwa-Polska.

Z kolei programy z udziałem Polski w ramach współpracy transnarodowej to:

1) Program Regionu Morza Bałtyckiego - oprócz Polski uczestniczą w nim: Dania, Estonia, Finlandia, Litwa, Łotwa, Niemcy (wybrane regiony), Szwecja oraz 3 państwa spoza UE: Białoruś (wybrane regiony), Norwegia i Rosja (wybrane regiony);

2) Program dla Europy Środkowej - oprócz Polski uczestniczą w nim: Austria, Czechy, Niemcy (wybrane regiony), Słowacja, Słowenia, Węgry, Włochy (wybrane regiony), Ukraina (wybrane regiony).

W ramach współpracy międzyregionalnej Polska uczestniczy w Programie Interreg IVC.

Tryb dostępu: http://www.ewt.gov.pl/WstepDoFunduszyEuropejskich/Strony/czymsafundusze.aspx, dnia 10.12.2012 r. 
Dodatkowo, Polska bierze udział w 2 programach transgranicznych (Litwa-Polska-Rosja oraz Polska-Białoruś-Ukraina) w ramach Europejskiego Instrumentu Sąsiedztwa i Partnerstwa (EISP), stanowiącego inicjatywę Komisji Europejskiej, której zasadniczym celem jest rozwój współpracy między Unią Europejską a państwami partnerskimi spoza UE. ${ }^{439}$

Z powyższego wyliczenia wynika, że polskie samorządy mają szereg możliwości realizacji inicjatyw związanych ze współpracą międzynarodową w oparciu o środki Unii Europejskiej. Rozmiar niniejszej publikacji nie pozwala na zaprezentowanie możliwości istniejących $\mathrm{w}$ ramach każdego $\mathrm{z}$ wyżej wymienionych programów. Chcąc jednak oddać istotę i logikę tychże programów, wydaje się być zasadnym scharakteryzowanie przynajmniej jednego z nich. Dobrym przykładem może być tutaj ostatni z wyżej wymienionych instrumentów, tj. Program Współpracy Transgranicznej Polska-Białoruś-Ukraina, który zawiera szeroką paletę działań możliwych do sfinansowania w ramach środków europejskich. Podstawą prawną Programu jest Rozporządzenie (WE) nr 1638/2006 Parlamentu Europejskiego i Rady z dnia 24 października 2006 r. określające przepisy ogólne w sprawie ustanowienia Europejskiego Instrumentu Sąsiedztwa i Partnerstwa. ${ }^{400}$ Zasady wdrażania programu określone są w Rozporządzeniu Komisji (WE) nr 951/2007 z dnia 9 sierpnia 2007 r., ustanawiającym zasady wdrażania programów współpracy transgranicznej EISP. ${ }^{441}$ Program Współpracy Transgranicznej Polska-Białoruś-Ukraina 2007-2013 został zatwierdzony przez Komisję Europejską decyzją C(2008)6411 $\mathrm{z}$ dnia 6 listopada 2008 roku. Czas trwania Programu został określony do 31 grudnia 2016 roku, okres wdrażania projektów do 31 grudnia 2014 roku zaś podpisywanie umów do 31 grudnia 2013 roku.

Głównym celem Programu jest wspieranie transgranicznych procesów rozwojowych. Cel ten ma być realizowany poprzez niekomercyjne projekty w ramach opisanych poniżej priorytetów. ${ }^{442}$

\section{Priorytet 1. Wzrost konkurencyjności obszaru przygranicznego}

W ramach priorytetu 1 przewidziano realizację następujących działań:

Działanie 1.1. Lepsze warunki dla przedsiębiorczości;

Działanie 1.2. Rozwój turystyki;

Działanie 1.3. Poprawa dostępności regionu.

Celem Działania 1.1. jest poprawa warunków rozwoju biznesu. Podniesienie jakości i dostępności infrastruktury, w tym infrastruktury nowych technologii, ma przyczynić się do wzrostu atrakcyjności inwestycyjnej, zarówno dla inwestorów

439 Tryb dostępu: http://www.ewt.gov.pl/WstepDoFunduszyEuropejskich/Strony/Programy_EWT.aspx, dnia 10.12.2012 r.

440 Dz. Urz. UE L.310 z 9.11.2006 r.

441 Dz. Urz. UE L.210 z 10.08.2007 r.

442 Tryb dostępu: http://www.pl-by-ua.eu/pl,3,23, dnia 10.12.2012 r. 
wewnętrznych jak i zewnętrznych. W ramach Działania 1.1. na wsparcie mogą liczyć działania o charakterze miękkim, których celem będzie rozwój społeczno-gospodarczy obszaru programu. Wsparcie uzyskają działania nakierowane między innymi na: promocję i marketing regionu, promocję handlową i inwestycyjną, rozwój małych i średnich przedsiębiorstw, rozwój lokalnych i regionalnych rynków pracy, rozwój społeczeństwa informacyjnego, nowych technologii, poprawę współpracy między biznesem i nauką, rekultywację i odnowę społeczną i gospodarczą obszarów zdegradowanych (w tym skażonych).

Celem Działania 1.2. jest poprawa i pełne wykorzystanie potencjału turystycznego obszaru przygranicznego. Obszar objęty programem dysponuje potencjałem rozwoju turystyki, w tym agroturystyki, dzięki wielu zasobom środowiska przyrodniczego i obiektom dziedzictwa kulturowego, tym niemniej infrastruktura turystyczna wymaga poprawy. Wsparcie skoncentruje się na rozwoju infrastruktury i usług turystycznych. Działanie 1.2. ma służyć promowaniu działań o charakterze miękkim, w tym: promocji regionalnej, rozwoju turystyki i agroturystyki oraz ochrony dziedzictwa kulturowego.

W ramach Działania 1.3. wspierane będą inicjatywy zmierzające do poprawy dostępności i jakości infrastruktury społecznej i gospodarczej, z naciskiem na infrastrukturę transportu, energetyki, systemy logistyczne, bezpieczeństwo transportu oraz zaopatrzenie w wodę. Rozwój infrastruktury zwiększy dostępność obszaru przygranicznego dla inwestorów, podniesie standard życia mieszkańców, a także jego atrakcyjność turystyczną i gospodarczą.

\section{Priorytet 2. Poprawa jakości życia}

Priorytet 2. skupia się na zarządzaniu zagrożeniami środowiskowymi i działaniach promujących zrównoważone wykorzystywanie zasobów naturalnych, rozwój odnawialnych źródeł energii i oszczędzanie energii. Celem jest również wzrost efektywności infrastruktury i procedur granicznych oraz zwiększenie bezpieczeństwa na granicach. W ramach tego priorytetu realizowane mogą być następujące działania:

Działanie 2.1. Ochrona środowiska na obszarze przygranicznym;

Działanie 2.2. Sprawne i bezpieczne granice.

Celem Działania 2.1. jest ochrona i poprawa jakości środowiska naturalnego. Poprawa jakości środowiska naturalnego prowadzi do podniesienia standardu życia mieszkańców oraz zwiększenia atrakcyjności obszaru jako celu turystycznego i inwestycyjnego. Cel ten powinien być realizowany przede wszystkim poprzez inwestowanie $\mathrm{w}$ infrastrukturę środowiskową o znaczeniu regionalnym lub lokalnym oraz polepszenie transgranicznej współpracy w dziedzinie ochrony środowiska naturalnego. 
Celem Działania 2.2. jest zwiększenie efektywności infrastruktury i procedur granicznych oraz podniesienie bezpieczeństwa na granicach. Większa przepustowość granic i ich bezpieczeństwo warunkują realizację pozostałych celów programu. Wykorzystanie i rozbudowa potencjału społecznego i gospodarczego obszaru objętego programem wymaga przede wszystkim usunięcia administracyjnych, instytucjonalnych i infrastrukturalnych przeszkód w bezproblemowym przepływie towarów, usług i ludzi przez granice.

\section{Priorytet 3. Wspólpraca sieciowa oraz inicjatywy społeczności lokalnych}

Priorytet 3. skupia się na działaniach promujących i wspierających współpracę transgraniczną poprzez rozbudowę zdolności instytucjonalnych jak również wspieranie lokalnych inicjatyw w zakresie współpracy międzyludzkiej. Priorytet ten przewiduje realizację następujących działań:

Działanie 3.1. Rozwój regionalnych i lokalnych możliwości współpracy transgranicznej;

Działanie 3.2. Inicjatywy społeczności lokalnych.

Celem Działania 3.1. jest poprawa transgranicznych zdolności do współpracy na poziomie lokalnym i regionalnym. Wspierane mają być przede wszystkim działania zmierzające do podniesienia instytucjonalnego potencjału współpracy. Rozwój tego potencjału nastąpi dzięki tworzeniu zinstytucjonalizowanych form współpracy transgranicznej. Promowana będzie także wymiana informacji i doświadczeń, współpraca sieciowa, w tym z wykorzystaniem Internetu.

Ogólnym celem Działania 3.2. jest społeczna, naukowa, edukacyjna i kulturalna integracja obszaru pogranicza. W ramach Działania 3.2. wspierany będzie rozwój transgranicznych kontaktów międzyludzkich i inicjatyw społecznych, współpracy naukowej i edukacyjnej, imprez kulturalnych i sportowych. Wspierana będzie współpraca transgraniczna szkół oraz uczelni wyższych, w tym wymiana studentów, uczniów, nauczycieli oraz naukowców, konferencje i seminaria naukowe. Wsparcie otrzymają projekty ukierunkowane na rozwój inicjatyw społecznych, imprez kulturalnych i sportowych. Wsparcie będzie udzielane projektom społeczności lokalnych, w tym ukierunkowanych na promocję i podtrzymywanie wspólnych tradycji obszarów przygranicznych. Tworzone będą warunki na rzecz ułatwienia wzajemnych kontaktów społeczności przygranicznych. Wsparcie uzyskają także działania na rzecz kultywowania różnorodności kulturowej, na rzecz mniejszości narodowych a także szeroko rozumianego rozwoju społeczeństwa obywatelskiego i wspólnot lokalnych.

W programie przewidziano realizację następujących typów projektów:

1) projekty zintegrowane, w których każdy z partnerów realizuje część działań wspólnego projektu na obszarze swojego terytorium, 
2) projekty symetryczne, w których podobne działania realizowane są po obu stronach granicy,

3) projekty proste wdrażane zasadniczo po stronie jednego kraju, ale wykazujące oddziaływanie także w kraju/krajach partnerskich.

Projekty zintegrowane są traktowane priorytetowo. Zgodnie z założeniami programu „władze lokalne” zostały wskazane jako jego najważniejsi beneficjenci. ${ }^{443}$

Przedstawiona wyżej charakterystyka Programu Współpracy Transgranicznej Polska-Białoruś-Ukraina jednoznacznie wskazuje na fakt, iż samorządy gminne i powiatowe mogą być jednym z jego głównych beneficjentów. Jednocześnie typy możliwych do realizacji działań są szeroko zakrojone i dotykają praktycznie wszystkich sfer działalności tych samorządów. Partnerstwo musi obejmować minimum jednego partnera polskiego oraz przynajmniej jednego partnera ukraińskiego lub/i białoruskiego. Wartość grantu nie może przekroczyć 90\% całkowitych kosztów kwalifikowanych projektu. Minimalna wartość projektu to 100000 EUR, zaś maksymalna wartość to 1500000 EUR. Planowany czas trwania projektu nie może przekraczać 24 miesięcy. Można zaryzykować tezę, iż wymogi te nie stanowią istotnej bariery, która uniemożliwiałaby samorządom aplikowanie do tego programu. Problemem mogą być jedynie ograniczone możliwości budżetu programu - całkowity budżet programu na lata 2007-2013 wynosi 202,9 mln EUR, w tym ze środków UE 186,2 mIn EUR. W momencie redagowania niniejszego tekstu nie ma jeszcze informacji co do wyników ostatniego naboru projektów w 2012 roku i możliwościach aplikowania do programu w roku 2013.

Niezależnie jednak od możliwości aplikowania do wyżej opisanego programu, czy też innych wymienionych wcześniej programów, z uwagi na stopniowe wyczerpywanie się alokacji zaplanowanych na perspektywę finansową na lata 2007-2013, pewnym jest, iż w kolejnym okresie programowania Europejska Współpraca Terytorialna pozostanie jednym z celów unijnej polityki spójności. Bezsprzecznie zapewnia ona stosowne ramy do wymiany doświadczeń między podmiotami krajowymi, regionalnymi i lokalnymi z różnych państw członkowskich, a także do podejmowania wspólnych działań w celu znajdywania wspólnych rozwiązań dla wspólnych problemów. Jest to szczególnie ważne w obliczu wyzwań, jakim muszą sprostać państwa członkowskie i regiony. Wyzwania te coraz częściej wykraczają poza granice jednego kraju czy regionu oraz wymagają podjęcia wspólnych, realizowanych we współpracy działań na stosownym szczeblu terytorialnym. Europejska Współpraca Terytorialna może więc także wnieść istotny wkład w szybsze osiągnięcie nowego celu Traktatu Lizbońskiego, ${ }^{444}$ jakim jest spójność terytorialna. W trakcie prac nad dokumentami określającymi zasady dystrybucji środków strukturalnych plano-

443 Tryb dostępu: http://pl-by-ua.eu/pl,3,16, dnia 10.12.2012 r.

444 Zob. pełny tekst Traktatu z Lizbony tryb dostępu: http://europa.eu/lisbon_treaty/full_text/index_pl.htm 
wanych na lata 2014-2020 zaproponowano odrębne rozporządzenie dotyczące Europejskiej Współpracy Terytorialnej. Ma ono zagwarantować sprawowanie lepszej kontroli nad międzynarodowym kontekstem programów oraz wprowadzić bardziej szczegółowe postanowienia dotyczące programów współpracy i działań. Nowe rozporządzenie formuluje bardziej systematyczne odwołania do roli, jaką w kontekście współpracy mogą odegrać europejskie ugrupowania współpracy terytorialnej (EUWT). W projekcie nowego rozporządzenia określono środki finansowe dostępne dla każdej z części programu oraz kryteria ich przyznawania państwom członkowskim. Przewiduje się kontynuację mechanizmu transferu środków przeznaczonych na wspieranie realizowanych we współpracy działań na granicach zewnętrznych Unii, które są finansowane z funduszy Europejskiego Instrumentu Sąsiedztwa i Partnerstwa (ENPI) oraz instrumentu służącego do finansowania pomocy przedakcesyjnej. Ponadto kryteria wyboru zdefiniowano bardziej rygorystycznie, aby zapewnić przyznawanie środków na działania rzeczywiście wspólne. Programy będą także poddawane ocenie pod kątem skuteczności. Sformułowano uproszczone ustalenia dotyczące wdrażania, zarządzania finansami i kontroli. Zredukowano na przykład liczbę organów zaangażowanych we wdrażanie programów oraz doprecyzowano definicje ról i obowiązków. Zaproponowano także zestaw ulepszonych wskaźników. ${ }^{445}$

Możliwości współpracy międzynarodowej powiatów i gmin stwarza również aktualnie wdrażany Program Operacyjny Kapitał Ludzki (POKL). W programie tym istnieje możliwość realizacji tzw. projektów współpracy ponadnarodowej. Zważywszy jednak na zakres działań przewidzianych w tego typu projektach, należy wskazać na bardzo ograniczony katalog działań, które mogą być w tej formule wdrażane. Projekt współpracy ponadnarodowej w rozumieniu POKL to projekt, który „zakłada wspólną realizację działań kwalifikowanych przewidzianych w załączniku nr 8 do Wytycznych, a także w przypadku, gdy wskazano na rzeczywistą wartość dodaną wynikającą ze współpracy i podpisano umowę o współpracy ponadnarodowej”. ${ }^{446}$ Projekty współpracy ponadnarodowej powinny przyczyniać się do osiągnięcia celów danego Priorytetu POKL, wykorzystując doświadczenia partnerów z innych krajów. Projekty te mogą korzystać z już gotowych i stosowanych w innych miejscach rozwiązań oraz przewidywać ich adaptowanie bądź wypracowywać nowe rozwiązania przy udziale partnerów z innych krajów, w tym wspólne rozwiązania problemów, z którymi borykają się wszystkie uczestniczące w projekcie podmioty. ${ }^{447}$ Wspomniany załącznik $\mathrm{nr} 8$ do Wytycznych (...), jako formy działań kwalifikowanych w ramach projektów współpracy ponadnarodowej wymienia:

1) organizowanie konferencji, seminariów, warsztatów i spotkan,

445 Polityka spójności 2014-2020. Inwestycje w rozwój gospodarczy i wzrost zatrudnienia, Urząd Publikacji Unii Europejskiej, Luksemburg 2011, s. 11-12.

446 Wytyczne w zakresie wdrażania projektów innowacyjnych i współpracy ponadnarodowej w ramach Programu Operacyjnego Kapitał Ludzki, Ministerstwo Rozwoju Regionalnego, Warszawa 2012, s. 6. 
2) prowadzenie badań i analiz,

3) przygotowanie, thumaczenia i wydawanie publikacji, opracowań, raportów,

4) adaptowanie rozwiązań wypracowanych w innym kraju,

5) doradztwo, wymiana pracowników, staże, wizyty studyjne,

6) wypracowywanie nowych rozwiązań. ${ }^{448}$

Pewne pole do działania dla powiatów i gmin w obszarze współpracy międzynarodowej istnieje również w ramach Programu „Uczenie się przez cale życie” (Lifelong Learning Programme). Jest to program Unii Europejskiej w dziedzinie edukacji i doskonalenia zawodowego przewidziany na lata 2007-2013. W programie kontynuowane są działania prowadzone wcześniej w programach SOCRATES, Leonardo da Vinci, Jean Monnet, e-Learning i European Language Label. Celem programu jest rozwój różnych form uczenia się przez całe życie poprzez wspieranie współpracy między systemami edukacji i szkoleń w krajach uczestniczących. Program ma się przyczynić do podnoszenia jakości i zwiększenia atrakcyjności szkolnictwa i kształcenia zawodowego w Europie. ${ }^{449}$ Możliwości działań w tym programie są jeszcze bardziej ograniczone, niż w przywołanym wcześniej POKL i sprowadzają się de facto do wizyt i wymian osób związanych z sektorem edukacji.

Podsumowując, należy stwierdzić, że programy Europejskiej Współpracy Terytorialnej są na chwilę obecną głównym źródłem umożliwiającym finansowanie współpracy zagranicznej powiatów i gmin ze środków UE i wszystko wskazuje na to, że pozostaną nim również w kolejnej perspektywie finansowej. W świetle powyższych informacji nie powinno być wątpliwości, co do tego, iż polskie samorządy powinny śledzić z uwagą rozwój prac nad dokumentami związanymi z perspektywą finansową na lata 2014-2020 również w aspekcie potencjalnej współpracy międzynarodowej. Mając też na uwadze szerokie spektrum działań możliwych do realizacji w ramach Europejskiej Współpracy Terytorialnej, czego dowodem jest chociażby szczegółowo scharakteryzowany wyżej Program Współpracy Transgranicznej Polska-Białoruś-Ukraina, jak też zważywszy na zapowiedź „lepszej legislacji” w tej materii, wydaje się, iż może to być dobre źródło przynajmniej częściowego zniwelowania problemów, z którymi borykają się na co dzień samorządy gminne i powiatowe.

449 Tryb dostępu: http://www.llp.org.pl/, dnia 10.12.2012 r. 


\section{THE POSSIBILITIES OF FINANCING THE INTERNATIONAL COOPERATION OF MUNICIPALITIES AND DISTRICTS FROM EUROPEAN UNION FUNDS}

The international cooperation of Polish municipalities (gminas) and districts (poviats) is a common practice. According to Polish legislation territorial communities have good possibilities for international cooperation and there is no strong legal limitation in this matter. After Poland's accession into the European Union, Polish territorial communities received the possibility of financing their international cooperation from EU funds. In the period 2007-2013 the main instrument of financing such initiatives is a separate objective of the European Union Cohesion Policy - the European Territorial Cooperation (ETC) objective. There are three types of such cooperation: cross-border, transnational and interregional. These three types of cooperation are implemented by European Territorial Cooperation Programmes. Poland is participating in total in 10 such programmes but within the scope of the article it is not possible to describe them all. Additionally, Poland is involved in the European Neighbourhood and Partnership Instrument (ENPI) which is the European Commission's initiative concerning cross-border cooperation with countries outside the European Union. Within the framework of this initiative Poland is involved in the Cross-border Cooperation Programme Poland-Belarus-Ukraine 2007-2013. This programme is a very good example of how a wide range of activities can be undertaken by municipalities and districts in the area of international cooperation. There are also other possibilities of financing the territorial communities' international cooperation- e.g. the Human Capital Operational Programme or the Lifelong Learning Programme - but there is a very poor range of activities which concern the training and educational sector and which are connected mainly with experience exchange. There is no doubt that the European Territorial Cooperation is actually a main source of financing for the international activities of territorial communities. We can assume that it will also be the most important tool of their international cooperation also in the period 2014-2020.

Keywords:

EU funds, financing the international cooperation, EU funds governance, transboundary cooperation 